\title{
6.22 Методичний супровід формування інструментально-виконавської компетентності майбутніх учителів музичного мистецтва
}

Сучасні реалії компетенізації освітнього процесу потребують від закладів вищої педагогічної освіти впровадження компетентнісного підходу у викладання дисциплін музично-виконавського циклу та створення умов для повноцінної самореалізації майбутніх фахівців. Проте на теренах музично-педагогічної освіти впровадження названого підходу відзначається складністю як у теоретичній, так і в практичній площині, потребуючи систематизації у виокремленні фахових компетентностей майбутнього вчителя музичного мистецтва, зокрема висвітлення та деталізація змісту інструментальновиконавської компетентності.

Джерельну базу теоретико-методичної аргументації процесу впровадження компетентнісного підходу в освітній простір та формування інструментально-виконавської компетентності вчителя музичного мистецтва складає науковий доробок провідних українських та зарубіжних науковців Г. Селевка, І. Зимньої, Н. Кузьміної, Л. Митіної, А. Хуторського, Н. Гуральник, Т. Жигінас, О. Максимова, О. Михайличенка О. Олексюк, Н. Миропольської, Г. Ніколаї, О. Отич， Г. Падалки， О. Ростовського， О. Рудницької， в яких розкривається багатовекторність змісту музично-педагогічної підготовки та опосередковано висвітлюється сутність означеної компетентності. Дослідники акцентують увагу на розкритті сутності художньої творчості, символічній природі та специфіці виражальних засобів музичного мистецтва, різновидах мистецьки традицій у музичному виконанні.

Психологічний базис формування інструментально-виконавської компетентності вчителя музичного мистецтва віднайдено у працях Л. Бочкарьова, О. Винокурової, О. Готсдинера, С. Корлякової, О. Лучиніної, Г. Овсянкіної, А. Торопової, в яких окреслені основи сприйняття та розуміння художнього змісту музичних творів, суб'єктивні та об'єктивні чинники 
виконавської інтерпретації, специфіка процесу формування виконавських вмінь та сценічної витримки.

У музично-виконавській діяльності науковцями зосереджується увага на продукуванні оптимальної емоційної інтенсивності, тобто викликання емоцій, необхідних для втілення художнього образу музичного твору в потрібний час та утримування їх інтенсивності та продовжності на необхідний час, що має велике значення для проектування та досягнення піаністичного успіху при виконання музичних творів (Б.Берман)[565, с. 134]. Дане твердження апелює до акторської майстерності, притаманної театральному мистецтву. У концепції видатного театрального режисера, актора, педагога та реформатора К. Станіславського зазначається, що сценічні почуття грунтуються на глибинних пластах емоційної природи людини. Артист на сцені відчуває двоїсті почуття: 3 одного боку він проживає емоції, закладені у художньому образі, з іншого - відчуває естетичні почуття як творець, художник. Вступаючи між собою у взаємодію ці почуття і створюють феномен сценічності. К.С. Станіславський вважав, що творче сценічне самопочуття повинно і може бути створеним свідомо. Знаходячись в відповідно створеному сценічному самопочутті, актор проходить через етапи інтуїтивного, підсвідомого пошуку (передчуття образу), переживає момент відкриття і далі розвиває образ у емоціях та фізичній дії [566, с. 94-114].

В методиці А..Алексєєва розглядається емоційний взаємоконтакт слухацької аудиторії та музиканта-виконавця, що надає останньому творчих сил, відчуття повної духовної та фізичної свободи для безперешкодного втілення художніх намірів. Автор наголошує на тому, що це дорогоцінне самопочуття необхідно зберегти у емоційній пам'яті та намагатися кожного разу викликати його під час гри. Найкраще в цьому допомагає захопленість музикою, що виконується та проникнення до їі глибинного змісту [567, с. 274].

У площині психологічної науки виділяється оптимальний емоційний стан, необхідний для успішного виконання будь-якої діяльності. Конкретизуючи зміст цього поняття науковці апелюють до закону Йоркса-Додсона, згідно 3 яким певний рівень емоційної збудженості забезпечує підвищення ефективності 
діяльності людини, а емоційна перенапруга приводить до зниження працездатності. За твердженням авторів закону, залежність продуктивності діяльності від рівня пов’язаної з нею активації має вигляд інтровертованої Uобразної кривої, що відображає рівень продуктивності людини, яка спочатку зростає швидко, пропорційно до росту рівня емоційної збудженості, а потім іiі ріст уповільнюється і високий рівень збудженості вже вносить дестабілізацію у процес діяльності та приводить до зниження іiі інтенсивності. [568, с. 216-218]. Словесна характеристика музичних переживань не задовольняє нас тому, що саме почуття стає в музиці могутнім пізнавальним засобом, багатшим i зрозумілішим, ніж вербальна характеристика. Таке піднесення пізнавальної ролі емоції можливе завдяки позитивним змінам, які мистецтво вносить у свідомість людини. За визначенням О.Костюка, першоджерелом цих емоційно-естетичних переживань є виразний зміст прослуханого твору. Разом з тим, слід мати на увазі, що емоційно-естетичний відгук людини на музику обов'язково несе на собі відбиток тієї епохи і того суспільного середовища, в якому вона живе. Автор стверджує, що емоційно-естетичний відгук слухача має двоїстий характер. 3 одного боку емоція виступає як супровід сприймання, а з другого увіходить у процес сприймання як складова його частина. Ці дві сторони музичного переживання найтісніше між собою пов'язані, аж до ілюзорного заміщення однієї другою, але все ж суть справи визначає друга сторона, а саме те, що переживання є необхідним компонентом музичного сприймання [569, с. 72]. .

Б. Теплов справедливо наголошує на внутрішній емоційності музичного пізнання дійсності: “Переживання музики має бути емоційним, але воно не має бути тільки емоційним. Сприймання музики йде через емоції, але емоцією воно не закінчується. В музиці ми через емоцію пізнаємо світ. Музика є емоційне пізнання“" [570, с. 27]

Почуття та емоції в музичному мистецтві $\epsilon$ могутнім пізнавальним засобом, багатшим і зрозумілішим, ніж вербальна характеристика. Відмінність музичного пізнання полягає у взаємодії емоцій та інтелекту, оскільки музика породжує “знання-переживання”. Таке піднесення пізнавальної ролі емоції 
можливе завдяки позитивним змінам, які мистецтво вносить у свідомість людини.

У контексті формування інструментально-виконавської компетентності майбутнього педагога-музиканта виконавство розуміється як проникнення до художньої та змістової сутності музичного твору, осягнення музичного образу за допомогою реалізації аксіологічних детермінант його автора та передбачає наявність: 1) свідомого використання духовних ресурсів особистості у виклику психологічного стану готовності до творчого «подвижництва», до пошуку «художнього відкриття»; 2) розгляду творів, що виконуються у метафоричній множинності виконавських прочитань, включаючи “перевиконання” педагогом рекомендованого твору та “обігравання” його у самих різних концертних умовах виступу; 3) проведення у процесі підготовки виконуваної музики до публічного показу з широким обговоренням із застосуванням комплексних знань, які освоюються у циклі обов'язкових музичних, гуманітарних та мистецтвознавчих дисциплін музичного вишу; 4) використання «творчого експерименту» подання виконуваних творів у риторичній множинності, виходячи з орієнтації на тип аудиторії; 5) усвідомлення зіграної та планованої до виконання музики у контексті сукупних артистичних та педагогіко-просвітницьких умов діяльності музиканта.

Виконавська діяльність майбутнього вчителя музичного мистецтва потребує контакту зі слухацькою аудиторією, котрий створюється на основі спільного емоційно-почуттєвого проживання художньої ейдетики музичного твору. Виникнення «сценічних почуттів» музиканта безпосередньо пов’язане 3 його минулим емоційним досвідом. Адже викликати в собі та відчути необхідне переживання музикант-виконавець може тільки тоді, коли воно вже має аналог пережитого у емоційній пам'яті і його можна віднайти, порівняти та поєднати 3 умовним сценічним подразником та відтворити спеціальними зображальними засобами. В цьому випадку сила та яскравість почуттів, які переживає митець досягають такої інтенсивності, якої неможливо досягнути в реальному житті. 
Музично-емоційні враження суб’єкта важко реєструвати. Наука поки що не знайшла задовільних засобів фіксації музичного переживання, якому притаманні часовий розвиток i емоційна та естетична насиченість. Взаємопроникнення емоційно-естетичного переживання музики та формування інструментально-виконавської компетентності майбутнього педагога-музиканта відбувається у площині когнітивних та емочійних процесів віддзеркалюючи рівень художньо-музичних знань, розуміння мистецтва у єдності змісту та форми, сприйняття емоційної ейдетики музичного мистецтва, проникнення до змістовності та завдань художнього виконання з метою проектування власних емоційно-естетичних переживань на слухацьку аудиторію, рефлексивної трансформації музичних емоцій до рівня естетичного переживання. Змістовність музичних образів полягає в силі естетичного переживання, тобто слухач повинен насамперед пройматись тими почуттями, які відображені в музиці, не копіювати чиїсь переживання, а переживати власні, адже не існує емоцій поза конкретними обставинами та певними життєвими ситуаціями, якими вони викликані.

Розглядаючи емоції мистецтва, В. Н. Холопова виділяє серед них ті, що відображають різноманітні аспекти емоційного відгуку людини: 1) емоції захоплення майстерністю мистецтва; 2) суб'єктивні емоції музиканта-практикавиконавця; 3) відображення в музиці емоцій (емоції втіленого в музиці образу); 4) специфічні природні емоції музики (емоції природного музичного матеріалу) [571, c. 97].

Як було вказано раніше, виконавська діяльність майбутнього вчителя музичного мистецтва потребує контакту зі слухацькою аудиторією, котрий створюється на основі спільного емоційно-почуттєвого проживання художньої ейдетики музичного твору. Музично-емоційні враження суб'єкта важко реєструвати. Наука поки що не знайшла задовільних засобів фіксації музичного переживання, якому притаманні часовий розвиток і естетична наснаженість.

Проаналізувавши вказане вище, ми виділили чинники взаємопроникнення процесів емоційно-естетичного переживання музики та розвитку виконавської майстерності студента-піаніста, до них слід віднести: рівень художньо-музичних 
знань (широта їх знайомства 3 національним, російським, українським, слов'янським та зарубіжним мистецтвом); здатність розуміти мистецтво у єдності змісту та форми, тобто освоєння художньо-музичного сприймання, емоційної ейдетики музичного мистецтва, рефлексивної трансформації музичних емоцій до рівня естетичного переживання; вміння аналізувати музичні твори з точки зору їх змістовності та завдань художнього виконання з метою проектування власних емоційно-естетичних переживань на слухацьку аудиторію (спочатку у систему відносин “викладач-студент” 3 подальшим розширенням аудиторії слухачів до однокурсників, студентів старших курсів, слухачів масових концертних заходів); готовність студентів до музично-виконавської mворчості, котра спонукається емоційно-естетичним переживанням музичних творів.

У контексті формування інструментально-виконавської компетентності емоційно-естетичне переживання музики визначається як встановлення особистістю внутрішнього емоційного зв'язку зі змістом художньо-музичного образу з метою отримання естетичної насолоди та втіхи.

При побудові методичної моделі акцентуємо увагу саме на емоційному та естетичному аспектах формування інструментально-виконавської компетентності студентів-піаністів. і вважаємо доцільним розкрити етапність формування емоційно-естетичного переживання як інтеріорізованого процесу свідомості людини. Побудова моделі сприяє упорядкуванню та систематизації інформації про об’єкт, що досліджується, та створенню відповідного методичного супроводу..

Основою емоційно-естетичного переживання, за переконанням О.Костюка, є емоційний відгук, який породжується суб’єктивним оцінним ставленням людини до естетичного явища. Автор висвітлює сутність емоційноестетичного переживання, описуючи процес сприймання музики: “звучання музики пробуджують у серці слухача багатобарвну гаму витончених емоційних переливів i яскравих афективних спалахів, предметних почуттів та ледь вловимих настроїв” [569, с.20]. 
Більш складну схему переходу емоційного відгуку в емоційно-естетичне переживання ми споглядаємо у наукових працях представників феноменологічної естетики, зокрема у Р. Інгардена, який визначає найважливіші особливості естетичного переживання і вважає, що естетичне переживання не $\epsilon$ «миттєвим переживанням», «миттєвим відчуттям», а становить складний процес, який має різні фази та протікає дуже своєрідно. Зазначена Р. Інгарденом своєрідність залежить від рівня професійної підготовки реципієнта й зумовлюється складністю чи простотою самого предмета сприймання, адже естетичне переживання може викликати i кольорова пляма i звук голосу i звучання музичної інтонації. Весь реальний предмет може сприйматися на рівні чуттєвого споглядання, а потім, зазначає Р. Інгарден, починають формуватися фази естетичного переживання.

Специфіка виникнення естетичного переживання, за Р. Інгарденом, емоційне враження від певної якості предмета (кольору, гармонії поєднання барв, мелодії, тощо) Ці якості роблять нас небайдужими до предмета споглядання концентрують нашу увагу та викликають у нас особливу попередню емоцію, яка дає поштовх процесові естетичного переживання. Між попередньою емоцією і естетичним переживанням у концепції Р.Інгардена вибудовано певні етапи “сходинки”, спираючись на які можна аналізувати внутрішню складність естетичного-переживання: попередня емоція породжує стан збудження на основі якого актуалізується бажання оволодіти предметом споглядання, оскільки даний предмет викликає здивування і як результат формується складне інтенціальне естетичне переживання [цит. за 8., с. 94-99].

Складним та оригінальним у даному контексті є дослідження М. Сови, яка розглядає процес формування емоційно-естетичного-переживання через призму особистісної рефлексії, та іiі аналогії - “музичної рефлексії. Концептуальне уявлення про музичний твір та осмислення власної інтелектуальної та емоційної діяльності, на думку автора, відбувається в процесі рефлексивного акту. Музична рефлексія характеризується послідовними ієрархічно залежними рівнями свідомості реципієнта і веде до перехрещення його духовного світу та 
ейдетики (образності) музики. Відповідно властивостям музичної свідомості, що визначають контакт людини з музикою, М. Сова виокремлює чотири основні ступені рефлексивного акту:

I ступінь - на першому ступені емоційно-смислового пошуку «музичної істини» здійснюється входження в об’єктивну музичну реальність, відбувається сприйняття об'єктивного мистецького твору, особистісний смисл якого належить предметній стороні свідомості суб'єкта. Саме з відчуття об'єктивності музичного твору, занурення в його зміст з метою усвідомлення життєвого світу музики і починається рефлексія;

II ступінь - на даному ступені рефлексивного акту увага реципієнта переноситься з об'єктивного музичного буття на власні особливості сприйняття музики. Зацікавленість безпосередньою предметністю змінюється на контактування 3 більш глибинними прошарками власного «Я». Реципієнт класифікує музичні враження та реакції на них , сприймає самого себе в якості дослідника власних думок, почуттів, спостережень, міркувань, які виникають за рухом естетичних почуттів.

III ступінь - внаслідок своїх інтенціональних переживань музичні враження від твору набувають особистісно-суб'єктивного смислу, композиційні форми зводяться до поетично-інтенціональних форм, тому даний ступінь рефлексії можна розглядати як повернення від суб'єктивності до об'єкту сприйняття через комплекс об'єктивних і суб'єктивних інтерпретацій музики на основі уявлень, безпосередньо пов'язаних з конкретним мистецьким твором. У такий спосіб усвідомлюється смисл твору, а його ейдос поєднується зі суб'єктивною інтенціональністю реципієнта;

IV ступінь - на цьому ступені музичної рефлексії активізується включеність власного «Я» в концептуальне розуміння музики. Діяльність свідомості набуває синтетичного характеру, музичне мислення проявляється через двоєдині діалектичні пари: чуттєве і понятійне, абстрактне і конкретне, емоційне і раціональне, індивідуально-інтуїтивне і художньо-образне. Сплав акустичних процесів та репрезентованих ними психічних станів людської 
чуттєвості означає розкриття естетичної ейдетики музики та завершення переходу від зовнішньої предметності звукового матеріалу на початковому рівні музичної свідомості до внутрішнього суб'єктивного саморозвитку, тобто до саморефлексії особистості. На розглядуваному рівні рефлексивного акту завершується перетворення музичного твору в естетичний об'єкт [573, с.72-75].

У контексті нашої роботи саме останній - рефлексивний - підхід $є$ найбільш прийнятним та доцільним. Психологами виявлено, що студентству притаманна підвищена емоційність, висока самооцінка i, разом 3 тим, конформізм та часто буденне відношення до звичайного, здатність за одним фактом робити загальні висновки.

Процес виконання музичного твору - це складний пізнавальний акт. Рівень осягнення емоційно-естетичного змісту музики у кожного студента відбувається по різному, в залежності від їх індивідуальних особливостей та попередньо набутого досвіду. Для кращого освоєння музичних творів студентами, на нашу думку, необхідно врахувати наступні критерії добору творів для музичного виконання, а саме: 1) загальний емоційний настрій твору; 2) змістовність твору; 3) доступність для музичного осягнення; 4) рівень впливу даної музики на виконавця та його ставлення до музики, що виконується; 5) відповідність чи не відповідність складності музичного матеріалу до індивідуальних професійних можливостей студента-виконавця. Метою запропонованою нами моделі $\epsilon$ формування інструментально-виконавської компетентності майбутніх учителів музичного мистецтва. Стратегія побудови моделі передбачає опору на індивідуальні особливості музичного розвитку кожного студента, емоційне ставлення до інтонаційної природи музики, готовність до сприйняття нової музично-інтонаційної інформації.

Методична модель формування інструментально-виконавської компетентності майбутніх учителів шляхом актуалізації емоційно-естетичного переживання музики - це схематичне відображенням основних компонентів комплексного процесу музично-слухової, музично-аналітичної, музично-оцінної та музично-виконавської діяльності, метою якої $є$ створення музикантом 
переконливої виконавської концепції музичного твору та його досконале сценічне втілення з опорою на рефлексивне занурення до емоційно-естетичної ейдетики музики.

При створенні даної моделі ми враховували: психологічні особливості студентського віку; загальний рівень доуніверситетської музичної підготовки студентів та попередній на рівень їх виконавської майстерності у музичному виконанні твору; стан сформованості музично-виконавського досвіду та досвіду емоційно-естетичного переживання музики; методичну доцільність добору музичних творів, для збагачення музично-виконавського досвіду та емоційноестетичного відчуття студентів; особливості індивідуальної інтерпретації та індивідуальні відмінності сценічного втілення творів художнього змісту музичного мистецтва студентами у концертному виконанні.

Відповідно до вказаного вище, ми побудували методичну модель формування інструментально-виконавської компетентності майбутніх педагогів-музикантів, яка має три стадії із коплементарним (взаємопроникаючим) поєднанням компонентів. Особливість даної моделі у пріоритетному наближенні позицій «викладач» та «студент» до позиції «інструменталіст-виконавець» та у створенні на заняттях з основного музичного інструмента спільного поля емоційно-естетичних переживань.

I стадія - мотиваційно-підготовча - відображає послідовність процесу ознайомлення студентів 3 новим музичним матеріалом, завдяки якому народжується план емоційного проникнення до художнього змісту та ескіз виконавської інтерпретації в опорі на емоційно-естетичну ейдетику музичних творів. Послідовність процесу ознайомлення студентів з музичними творами передбачає: а) ескізне ознайомлення, при якому від студента вимагається самостійність осягнення емоційної палітри музичного твору, а роль викладач полягає у гнучкій-корекції емоційної ейдетики музичного твору, побудованої студентом; б) поникнення до художнього змісту на рівні фрагментарного сприймання та інтуїтивно-емоційного пережсивання передбачає створення студентом емоційної концепції за авторським задумом, в цьому випадку 
викладач покликаний також створити власну емоційну концепцію, яка співпадає iз задумом композитора та допомогти студенту скоригувати емоційний контент власної виконавської концепції; створення ескізу майбутньої художньої інтерпретації - позиції викладача i студента поєднуються спільному смисловому полі інтерпретації музичного образу та емоційного стану виконуваного твору. Схематично даний процес виглядає так:

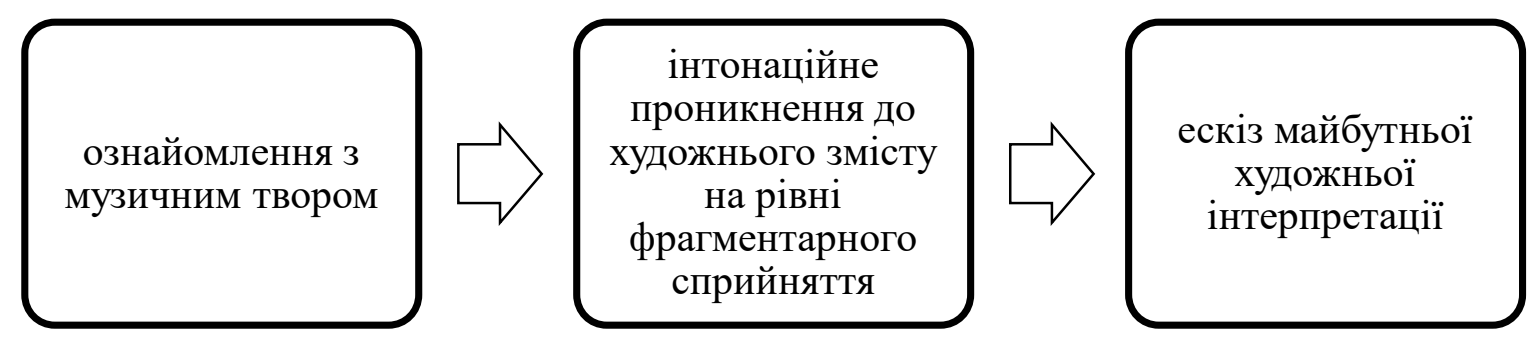

Рис.1. Послідовність прочесу ознайомлення студентів з музичним твором

Відповідно до вищезазначеного формуються складники I стадії методичної моделі:

- мотиваційний складник - має вигляд особистісних потреб студентамузиканта при ознайомленні 3 музичним твором, що відображається у визначенні виконавських цілей: «чув раніше - хочу спробувати», «хочу зможу», «чув в іншому виконанні - в мене вийде не гірше», «потрібно - значить зіграю» тощо;

- емоційний складник - характеризується впливом нових емоційних вражень, отриманих у процесі ознайомлення з музичним твором, на створення відповідного емоційно-піднесеного стану особистості, розкутості ініціативи, що відображається на якості емоційно-естетичного сприйняття твору;

- пізнавальний складник - при проникненні в емоційно-естетичну ейдетику виконуваної музики відображає комплексну дію взаємодоповнюючих компонентів, які базуються на попередньому досвіді музично-виконавського інтонування, а саме: асоціащуiŭ, що виникають у студентів при ознайомленні 3 музичними творами певних стилів, авторів, жанрів, фактурних особливостей 
тощо; осмисленому сприйманні нових музичних емоцій та емоційно-естетичних комплексів;

- рефлексивний складник - при ескізному «читанні» музичного твору виявляється як у посиленні слухового самоконтролю в особистості (тобто активізації в студентів інтонаційного слуху), так і в активізації їх музичного мислення, основу якого складає наявність органічного взаємовідношення орієнтуючої і контролюючої функцій (тобто роздвоєння уваги виконавця на звукову мету і на наступний контроль гри) в єдності з специфічними ігровими відчуттями.

II стадія - діяльнісно-практична - окреслює алгоритм процесу виконавського освоєння студентами музичних творів з детальним розумінням їх емоційно-естетичної і побудови та віднайденням шляхів сценічного втілення інтерпретації. Послідовність процесу засвоєння музичного твору на цій стадії зосереджена на технології виконавського втілення художнього образу, яка графічно відображається наступним чином:

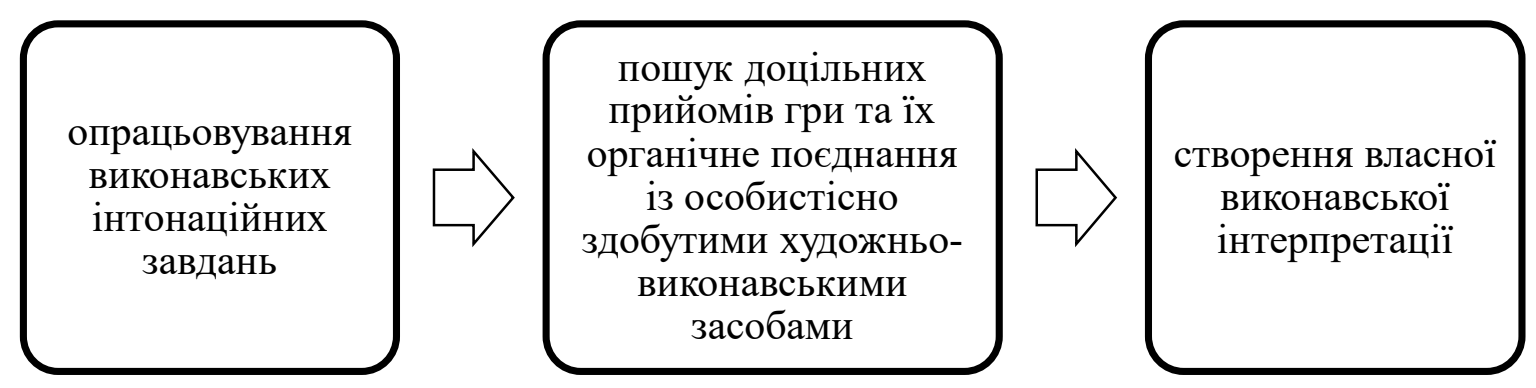

Рис.2. Послідовність процесу вивчення музичного твору

Еволюція змісту складників даної стаді зумовлюється актуалізацією виконавської технології втілення художнього образу:

- мотиваційний складник - віддзеркалює прагнення студента знайти індивідуально-неповторне поєднання загальновідомих виконавських прийомів та особистісних інтонаційно-виразних засобів втілення художньої інтерпретації музичного твору;

- емоційний складник - відображає переусвідомлення власного емоційного стану, а також його зіставлення із характерною для даного твору емоційно- 
смисловою сферою, що була закладена композитором, яке відбувається у виконавця в процесі інтонаційно-технічного опрацьовування музичного твору;

- пізнавальний складник - полягає у систематичному поповненні "емоційно-естетичного словника" студента, наявність відомостей у галузі музикознавства та додаткової історичної інформації 3 проведенням синестетичних паралелей. сприяє віднайденню власної інтерпретації;

- рефлексивний складник - уможливлює процес оволодіння емоційнохудожньо структурою твору 3 урахуванням існуючих норм i правил; співвіднесення та корекцію взаємовпливу внутрішньо-слухових і руховомоторних уявлень в процесі інтонування твору; посилення слухо-рухового контролю, для діагностування не лише стану роботи, але й усунення причин окремих недоліків та регуляції дій під час виконання твору; активізацію здатності керування власною виконавською діяльністю.

III стадія - аналітична - передбачає підведення підсумків щодо виконавського оволодіння емоційною ейдетикою музичного твору, а також практичними піаністичними прийомами та художньо-виразними засобами для iii втілення ï особливістю $є$ співпадання виконавських позицій викладача та студента під час аналізу кінцевих результатів процесу виконавського інтонування, вдосконалення емоційно-естетичної інтерпретації, музичної рефлексії у формі емоційно-естетичного переживання, постановки подальших виконавських цілей, шляхів збагачення барв емоційно-естетичного переживання у формуванні інструментально-виконавської компетентності майбутнього вчителя музичного мистецтва. Особливості даної стадії відображаються у наступному рисунку: 


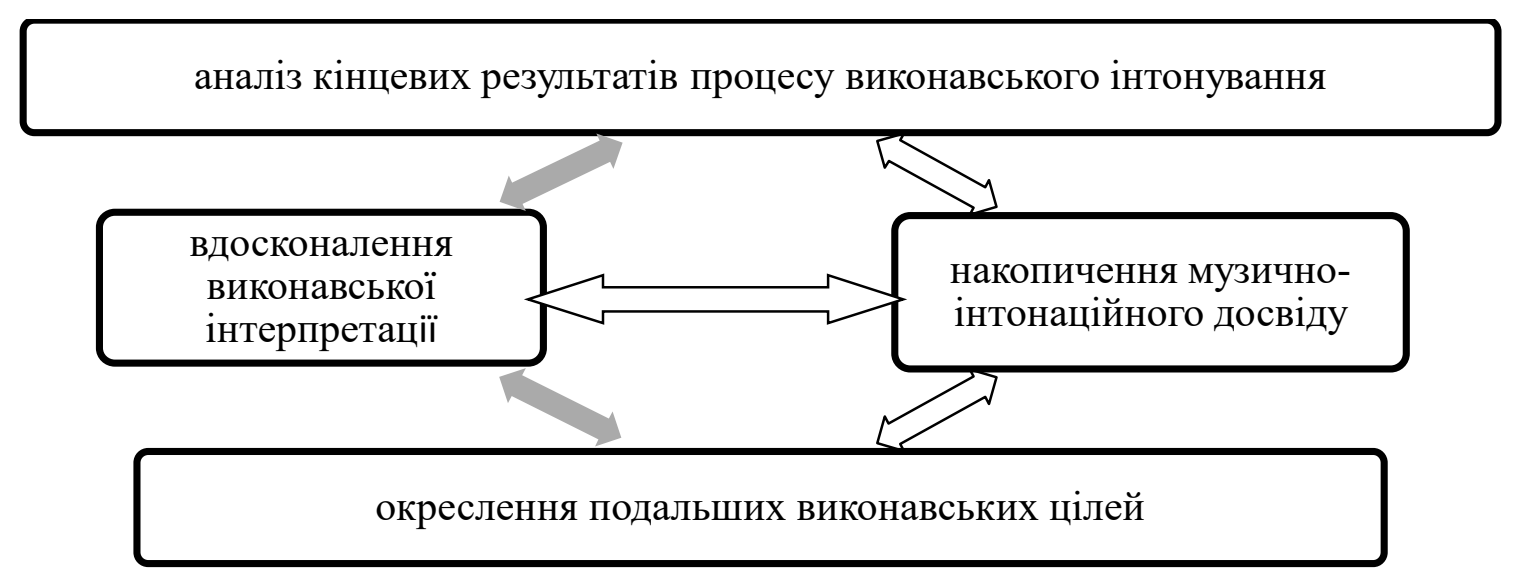

Рис.3. Послідовність процесу аналізу результатів сиенічного виконання музичного твору

На аналітичній стадії ії чотири складники виглядають наступним чином:

- мотиваційний складник - визначається знаходженням шляхів до подальшого вдосконалення власної інтерпретації вже виконаного музичного твору та віднаходженням підтвердження у наступній практичній діяльності власним здобутим виконавським вмінням та навичкам виконавського інтонування та емоційно-естетичного проживання художньої ейдетики музичного твору;

- емоційний складник - передбачає глибокий аналіз відповідності рівня емоційності інтонування із художньо-образним змістом твору та подальший пошук ключових інтонацій, що зроблять виконання ще більш емоційно забарвленим;

- пізнавальний складник - зорієнтований на осягнення виконавцем технології музично-виконавського інтонування даного твору з ії наступним креативно-модифікованим використанням, але вже на іншому музичному матеріалі;

- рефлексивний складник - передбачає враховування та збереження досягнутих результатів діяльності; надання об'єктивної оцінки власним проблемам при інтонуванні твору, коригування, згідно до потреб подальшої виконавської діяльності; формування найкращих якостей виконавця - 
стриманості, самовладання (включаючи емоційне), та витримки; аналіз якості набутих інтонаційно-виконавських умінь та навичок.

Підсумовуючи зазначимо, що методичний супровід формування інструментально-виконавської компетентності майбутніх педагогів-музикантів шляхом емоційно-естетичного переживання музики втілюється застосуванні методичної моделі як схематичного відображенням основних компонентів комплексного процесу музично-слухової, музично-аналітичної, музично-оцінної та музично-виконавської діяльності., Особливість даної моделі у пріоритетному зближенні позицій “викладач” та “студент” до позиції “піаніст-виконавець” та у створенні на заняттях 3 основного музичного інструмента (фортепіано) спільного поля емоційно-естетичних переживань, а результатом $є$ створення музикантом переконливої виконавської концепції музичного твору та його досконале сценічне втілення з опорою на рефлексивне занурення до емоційноестетичної ейдетики музики. 